\title{
MICRO FINANCE INSTITUTIONS AND THEIR IMPORTANCE IN GROWING ECONOMIC DEVELOPMENT: A STUDY OF RURAL INDIAN ECONOMY
}

\author{
Dixit Pankaj, Assistant Professor \\ Department of Accounting and Finance, Lebanese French University \& Department of \\ Commerce and Business Administration, M.M. College Modinagar, \\ C.C.S. University Meerut, India
}

\author{
Al-kake Farhad, Head of Department \\ Department of Accounting and Finance, Lebanese French University, Erbil, Kurdistan, Iraq
}

\author{
Ahmed Ramyar Rzgar, Dean \\ College of Business Administration and Economics, Lebanese French University, \\ Erbil, Kurdistan, Iraq \\ *E-mail: pdixit2989@gmail.com
}

\begin{abstract}
In a country like India 70 percent of the population lives in rural areas while the rest of the population i.e. 30 percent resides in urban areas and 60 percent approx. depend on agriculture (according to the World Bank reports. In this rural India with having second largest population needs NGOs like SHG needs cooperative helping hands. NonGovernment organization is playing crucial in the economic development of India. NonGovernment organization is not confine up to registered organization like big renowned NGOs its includes small level social help group i.e. Self Help Group on village level, local women skilled help group etc. The purpose of this research paper is to identify how microfinance is made available in the rural areas for needy people and also how the microfinance institutions can check or reduce the poverty with the help of providing microfinance. For critical analysis of the research, data has been collected through secondary available sources and comparative analysis has been done for reaching to conclusion.
\end{abstract}

\section{KEY WORDS}

Microfinance institutions, microfinance products, rural finance, banking system, microfinance, poverty alleviation.

The credit of introducing Microfinance goes to Dr. Mohammad Yunus, who suggested the idea of making small loans, which he funded himself, to women in Bangladesh making bamboo furniture who had previously relied on usurious loans to purchase raw materials. He discovered these very tiny loans, which traditional banks did not want to make due to the perceived risks and costs, could make a disproportionate difference to a poor person and given the chance they would pay them back creating a viable business model. He would go on to found Grameen Bank in 1983 and win the Nobel Peace Prize in 2006.

Kiva Microfunds (commonly known by its domain name, Kiva.org) is a non-profit organization that lends money by way of Internet to low-income people in over 80 countries. Kiva's mission is to lend money to more and more people for reducing poverty. Kiva was founded in 2005 after being inspired by the work of Dr. Mohammad Yunus. Kiva allows low income people, for as little as $\$ 25$, to help a borrower start or grow a business, to have finance for personal purposes.

Kiva has expended its network over the past ten years and has enabled more than 1.5 million people to fund over 2 million borrowers in over 80 countries. The result of which is that Kiva has lent approximate $\$ 1$ billion dollars to the borrowers which was repaid at a rate greater than $97 \%$. 
Microfinance refers to the affordable financial services which are provided to the low income people. Microfinance is a word that is closely associated with microcredit. Microfinance refers to the broad spectrum of providing financial services to the low-income people. Whereas, Microcredit is a small loan provided to the persons of below poverty line to make them self-employed. The scheme is offered to the people of below poverty line who lack collateral and are not eligible to take a loan in a traditional way. As Microcredit is a financial service provided in microfinance, the terms are used interchangeably by the people Microfinance is a universal term to describe financial services, such as deposits, instalment payments, loans, money payment services, money transfers, insurance, savings, microcredit services, fund transfers to entrepreneurs who lack access to traditional banking services. Microfinance institutions work in the directions to provide microfinance services to the low- income people.

Microfinance refers to those financial services like loans, insurance, savings etc which are provided to poor entrepreneurs and small business owners who are unable to take any bank loan and have no collateral. Most often, microloans are given to those living in stilldeveloping countries who are working in a variety of different trades, including carpentry, fishing and transportation.

Microloans typically are not more than several hundred dollars. Examples of uses include money for tools to start work in construction, or makeup and other supplies needed to become a cosmetologist. Because they are the ones that commonly use their profits to provide for their families with things like food, clothing, shelter and education, women currently comprise roughly two-thirds of all microfinance clients. The main aim of microfinance is to provide small loans so that they can easily invest in their small businesses and can tackle the problems of finance very easily. The micro loans are provided for a time period of six to one year without having any collateral security.

Microloans typically are not more than several hundred dollars. Examples of uses include money for tools to start work in construction, or makeup and other supplies needed to become a cosmetologist. Because they are the ones that commonly use their profits to provide for their families with things like food, clothing, shelter and education, women currently comprise roughly two-thirds of all microfinance clients. The main aim of microfinance is to provide small loans so that they can easily invest in their small businesses and can tackle the problems of finance very easily. The micro loans are provided for a time period of six month to one year without having any collateral security.

National Bank for Agriculture and Rural Development (NABARD) introduced Self-help group (SHG) - bank linkage programme 1992. SHG firstly introduced microfinance in India. No doubt this programme has proved to be very successful and also the most popular model of micro finance in India. There are other approaches like micro finance institutions (MFIs) established after SHG in the country.

Recognizing the potential of micro finance to positively influence the development of the poor, the Reserve Bank, NABARD and Small Industries Development Bank of India (SIDBI) have taken several initiatives over the years to give a further fillip to the micro finance movement in India.

Objectives of study:

- To understand the concept of microfinance, and delivery models of microfinance in India;

- To define features, role and importance of microfinance in India;

- To examine the current status and growth of microfinance in India;

- To suggest measures for making Micro Finance Institutions more efficient in credit;

- To introduce low income people with verities of Microfinance Products.

\section{METHODS OF RESEARCH}

This is a descriptive research paper based on secondary data. Data have been collected through books of references, publications of recent research papers available in different websites and magazines, newspapers, Research Articles, dissertations of the 
scholars, standard publication, E- Journals, periodicals, internet, RBI Report, Report of NABARD, Bharat Microfinance Report, The micro finance institution (development and regulation) bill, 2012, etc.

\section{LITERATURE REVIEW}

The earlier researchers have evolved that there are various institutions that helps people below poverty line to have small loans in order to fulfil their purposes. Self-help group (SHG) - bank linkage programme (SBLP) is an autonomous association of people united voluntarily to meet the needs of the common people. Also the Micro Finance Institutions aims at fulfilling the same purpose of providing microfinance in the rural areas.

It has been proved that microfinance is the tool to help poor family moved out of poverty and to contribute to the economy of a country by increasing their income generating capacity. Studies have shown with the microcredit provided by Grameen bank in Bangladesh $48 \%$ of the families below the poverty line have exit from poverty. According to some studies with microcredit $5 \%$ of the poor could exit the poverty line each year as it is an investment in human capital and improve people's life. Microcredit is an opportunity for the poor to realize their dreams. Microfinance is a strategic tool to trim down poverty and help the poor to participate in the social and economic life of a country. Microfinance helps the households not only to fulfil their present needs but also to plan accordingly for their better future.

According to the research conducted by World Bank, India is famous as home to almost one third of the world's poor (surviving on an equivalent of one dollar a day). There are many central and state government poverty alleviation programs activated in India, microfinance plays a major contributor to financial inclusion. Microfinance has made its contribution in reducing poverty from last few decades. There are various reports that show people have raised their income levels and standard of living with the help of microfinance.

Thus Microfinance plays a major role in development of Indian economy in following ways:

Credit to Rural Poor - financial institutions fulfil the credit needs of poor people by providing microfinance. Rural people are based on non- institutional agencies to fulfil their financial purposes. Micro financing helps the people to cater the needs of the poor people and make them economically and socially sound.

Tool for Poverty Reduction - with the help of microfinance people are able to get employment which helps them to have a good income and also helps to reduce the poverty.

Women Empowerment - women's economic empowerment refers to the improvement in the economic status of women by providing them the freedom to use their rights in a proper manner. There is more than \% of SHGs which are established by women. This is really a wonderful step that has been taken by the government for providing safety and security to women. Thus, microfinance helps the poor women to grow economically.

Economic Growth and Development - for the purpose of economic growth and development finance plays a vital role. Finance is the life blood for any organization or business. Financial institutions and government provides microfinance on a large scale to people that increase the production of goods and services. This increase leads to an increase in GDP and contributes to economic growth and development of the country.

Mobilization of Savings - saving is the main source for meeting the contingencies. Microfinance is a helpful tool that develops the habits of saving among people. The finance that is generated by way of savings are used to be provided as loans and credit to its members. Thus microfinance helps in mobilisation of savings.

Development of Skills - micro financing helps to get employment to the poor people. It also helps them to set up their own businesses and motivates them to become potential rural entrepreneurs. SHGs encourage its members to set up business units jointly or individually. They are also being provided training accordingly to operate their businesses. Thus micro finance plays a vital role for development of skills. 
Mutual Help and Co-operation - microfinance is a helping and co-operative tool for the poor and needy people. People can face the economic crises easily if they have the availability of microfinance.

Social Welfare - micro financing also aids in employment generation, this employment generation also helps to increase the level of income of people. They may go for better education, health, family welfare etc. Thus micro finance helps in social welfare.

The availability of credit and banking facilities to the poor segment of the society can be reached through Microfinance. The Government and the Reserve Bank of India have taken several steps like providing loans to the weaker section of society, declaration of rules and regulations for banks, guidelines for nationalization of banks, and low interest rate for the weaker section of society. It was, however, realized that further direct efforts were required to address the credit needs of poor people. In response to this requirement, the Micro finance was introduced in India by the establishment of SHG bank linkage programme (SBLP) in the early 1990s. At present, there are mainly two models for providing Microfinance in India SBPL model and the MFI model.

The SBPL model had more borrowers and loans outstanding in comparison with other models of Microfinance. SBPL model is recognized as largest Microfinance programme in all over the world as per its coverage. Apex Institutions like RBI, SIDBI, and NABARD have also taken a number of steps to drive movement of Microfinance programs in India. The developments relating to evolution of various models of the Micro finance movement are detailed in the present section. The Micro finance sector started getting recognition in India after the launch of the SBLP.

The concept of Microfinance in India had been coined forward since 1980s. There are various models which are used to provide microfinance as there is no any specific model which fits into all conditions. Each model has to be modified as per different situation and local requirements. For this purpose Microfinance Institutions have adopted various delivery models and they can be categorized in to following broad categories.

Self-help group was originated in India. These groups have contributed towards the rural development and spread in all parts of the country and growing day by day in terms of its numbers all over the country. These Groups are formed by Non-Government as well as Government organisations and are used as channels for various development programmes.

Self-Help Group is an association of generally up to 20 members (not exceeding 20 members). Self-Help Group refers to self-governed, peer controlled, informal group of people with same socio-economic background and having a desire to collectively perform common purposes. Here poor people voluntarily come together to save whatever amount they can save conveniently out of their earnings and they mutually agree to contribute the amount to a common fund and lend the money to the members for meeting their productive and emergent needs. These groups are helped by Government agencies or NGOs for members to come together for discussing and solving their common problems either financial or social through mutual help. An SHG can be all-women group, all-men group, or even a mixture of both men and women.

SHGs are well recognized and accepted by government, SHGs can open bank accounts in the name of SHG. They can also receive government grants and funds for development activities.

SHGs do not restrict their functions only to financial transactions. SHGs are often involved in many social activities. There are example where SHGs have taken up social issues and fought against social evils like alcoholism, violence, against women, dowry, getting into village politics and being elected as Sarpanch.

SHGs maintain their own books of accounts. They keep the records of their savings, money lending, Income and expenditures. Strong SHGs also prepare their Final Accounts and Income statements.

SHGs are based on a formal hierarchy in which they include a Group President, Secretary and Treasure. They all are elected by the group.

SHGs are more autonomous in nature as they decide their own rules and regulations.

SHGs mobilize thrift and rotate it internally. 
SHGs can hold bank account and can also borrow from banks and other financial institutions.

MFIs in India exist in a variety of forms like trusts registered under the Indian Trust Act, 1882/Public Trust Act, 1920; societies registered under the Societies Registration Act, 1860; Co- operatives registered under the Mutually Aided Cooperative Societies Acts of the States; and nonbanking financial companies (NBFC)-MFIs, which are registered under Section 25 of the Companies Act, 1956 or NBFCs registered with the Reserve Bank. These MFIs are scattered across the country and due to the multiplicity of registering authorities.

The four most important Micro Finance models in India are:

- Model I - individuals or group borrowers are financed directly by banks without the intervention/facilitation of any Non-Government Organisation (NGO);

- Model II - borrowers are financed directly with the facilitation extended by formal or informal agencies like Government, Commercial Banks and Micro-Finance Institutions (MFIs) like NGOs, Non Bank Financial Intermediaries and Co-operative Societies;

- Model III - financing takes place through NGOs and MFIs as facilitators and financing agencies;

- Model IV - is the Grameen Bank Model, similar to the model followed in Bangladesh.

Self Help Groups are successful in empowering women by providing direct and indirect benefits to them. SHGs are small in size generally $10-15$ members having limited in the types of financial services they can provide to its members. Federation of SHGs have more than 1000 members In Federated SHG model, there is a three tier structure the first tire is the SHG, the second tier is a cluster and the third tier is an apex body, which represents the entire SHG. At the cluster level, each SHG is represented by two of its members. The apex body usually made up of $10-15$ members and they form the link between the SHGs and the NGO which is supporting to them. With the help of federations and NGO with limited resources, it has impact on a large number of poor people. Examples of Federated Self Help Group model are PRADAN, Chaitanya and SEWA.

In this model, the bank works as a lender and the role of MFI is to act as an agent for performing the tasks of lending, credit facilities and recovery of the money, while the borrower is the individual. In Bank Partnership model Microfinance institutions acts as an agent of bank. Microfinance institutions are only concerned with dealing with clients for granting loan to final repayment. In this model MFI for larger funding access holds the borrower loan on its account for some time and refinance through the mean of securitization.

Grameen model is based on the concept of joint liability. It is the brainchild of Prof.. Muhammad Yunus, founder of Grameen Bank in Bangladesh. Grameen model is the most accepted and prevalent micro-finance delivery model in the world today. Many MFIs have accepted the model as it has high focus on standardization and discipline.

Grameen model is a joint liability group model. Here five-member groups are formed and eight such groups form a Center. So there are total 40 members $(8 \times 5)$. However, over the years people have experimented with Centers of different sizes and now there are variations of 5-8 groups within a Center. Center is the operational unit for the MFI, which means that MFI deals with a Center as a whole. In Grameen model meetings are held only at central level and the individual groups do not meet. All the members are jointly responsible for the repayment. If all the members make default in the repayment, MFI recovers full money from center.

Some other features of Grammen Model are:

- The group meeting take place every week;

- Interest rate are charged on flat basis (iii)

- MFI staff conducts the meeting;

- MFI staff conduct the center meetings on all transactions;

- Low transaction costs;

- Loans are collateral free;

- Repayment of loans in small and short interval; 
- Quick loan sanctions with little or no paper works.

Repayment of loans in small amount is one of the major reasons of high loan recovery rate of a Grameen Bank.

SHG and Grameen model have originated with two different approaches. SHG model has been developed with holistic view of development and empowerment of society where financial transactions are only one part of it. While Grameen model is specifically focused on providing financial services to the low-income clients.

In 1970s Grameen Bank model was launched in village area of Bangladesh to empower the poor people through Microfinance. After great success of GB Model it was created as formal Bank under special Law in 1983. The bank is owned by the poor burrowers mostly women. The Grameen bank eliminates the concept of collateral security for taking loan from bank and upturned the conventional banking practice. It is formed on mutual trust and provides credit facilities for self employment and profit making activities to low income people. The main feature of Grameen bank model is it provides door step service to poor people. In India Grameen bank model was adopted by CASHPOR financial and technical limited, SHARE Microfinance limited, and Activist for social alternatives (ASA).

Joint Liability Group is usually a group of five to ten who come together to borrow from an MFI. The members in a JLG are also from similar socio-economic backgrounds and usually the same village. A JLG is different from SHGs in that the members share liability, or stand guarantee for each other. In Joint Liability Group, The borrowers make a group among themselves and the microfinance institutions give loan to that group. One person in that group is appointed as leader of the group and each person is responsible for the loan taken by any member of the group. If any one person in the group defaults then other group members will have to pay for that.

It is very much costlier to provide financial services to the needy ad poor people in developing countries. The cost is one of the biggest reasons why traditional banks don't make small loans, the resources required for a $50 \$$ loan is the same as for a $1000 \$$ loan.

Data from the Micro Banking Bulletin reports that 63 of the world's top MFIs had an average rate of return, after adjusting for inflation and after taking out subsidies programs, of about $2.5 \%$ of total assets. This lends to the hope that microfinance can be sufficiently attractive for investors, as well as the mainstream in the retail banking sector.

Table 1 - Typical microcredit products

\begin{tabular}{|c|c|c|c|}
\hline Product & Purpose & Terms & Interest rate \\
\hline $\begin{array}{c}\text { Income Generation } \\
\text { Loan (IGL) }\end{array}$ & $\begin{array}{c}\text { Income generation, asset } \\
\text { development }\end{array}$ & 50 weeks loan paid weekly & $\begin{array}{c}12.5 \% \text { (flat) } 24 \% \\
\text { (effective) }\end{array}$ \\
\hline Mid-Term Loan (MTL) & $\begin{array}{c}\text { Same as IGL, available at middle } \\
\text { (week 25) of IGL }\end{array}$ & 50 weeks loan paid weekly & $\begin{array}{c}12.5 \% \text { (flat) } 24 \% \\
\text { (effective) }\end{array}$ \\
\hline Emergency Loan (EL) & $\begin{array}{c}\text { All emergencies such as health, } \\
\text { funerals, hospitalization }\end{array}$ & 20 weeks loan & $0 \%$ Interest free \\
\hline Individual Loan (IL) & $\begin{array}{c}\text { Income generation, asset } \\
\text { development }\end{array}$ & $\begin{array}{c}1-2 \text { years loan repaid } \\
\text { monthly }\end{array}$ & $\begin{array}{c}11 \% \text { (flat) } 23 \% \\
\text { (effective) }\end{array}$ \\
\hline
\end{tabular}

The Income Generating Loan is used for a variety of activities that generate income for their families. For this purpose the Clients submit a loan application and collect the amount of the loan after one week as the application is approved. The clients are being given the facility to pay the loans in 50 equal, weekly instalments. Once the previous loan is completed a new application for further loan can be submitted by the client.

The Mid Term Loan is given to the clients after 25 weeks of repaying their IGL loan. Only if the client has not taken the maximum amount of IGL, he can be granted to take MTL. The clients are being given the facility to pay the loans in 50 equal, weekly instalments. Once the previous loan is completed a new application for further loan can be submitted by the client. The terms and conditions would be same as in case of IGL.

The Emergency Loan is available to all clients over a year. The amount of such loan is small as compared to income generating products. This loan is provided to meet the expenses such as funerals, health, hospitalization, prenatal care and other crisis situations. 
Here the clients are being given the facility to pay the loans in 20 equal instalments. Such kinds of loans are $0 \%$ interest free.

The Individual Loan is designed for clients and non clients that have specific needs such as Income generation, asset development etc. The clients are being given the facility to pay the loans within 1-2 years, monthly instalments.

There are some restrictions regarding what the money is used for. Usually micro credits can't be used for the purposes like:

- Payments of other loans or other debts;

- Production of tobacco and liquor;

- Forming turnover capital of trade and intermediary business;

- Organization or purchasing products for gambling or entertainment services for the population;

- Establishing trading points;

- Purchase of property that's not used for business.

Microfinance Institutions are introducing lot of new products to help the poor people in their needs and also focusing on raising their standards of living. This shows the growth of the microfinance sectors year after year. The different products common used in the microfinance sector today is:

Micro savings - micro saving refers to small deposit account for the lower income families for depositing funds for the future requirements. This account is as similar as a saving account, though the amount which is kept in this account is small. The amount of balance of this account is low,

The minimum balance requirements are often waived or very low, allowing users to save small amounts of money and not be charged for the service.

Micro insurance - gives the entrepreneurs the chance to focus more on their core business which drastically reduces the risk affecting their property, health or working possibilities. The is different types of insurance services like life insurance, property insurance, health insurance and disability insurance. The spectrum of services in this sphere is constantly expanded, as schemes and terms of providing insurance services are determined by each company individually;

Micro leasing - for entrepreneurs or small businesses who can't afford buy at full cost they can instead lease equipment, agricultural machinery or vehicles. Often no limitations of minimum cost of the leased object.

Money transfer - people always feel the need to transfer the money from one place to another as per their requirements. Sometimes they also have to transfer the money overseas to their friends or relatives. A number of commercial banks provide the facility of international money transfer without opening current accounts. Such banks are Western Union, Money Gram, and Anelik. Though these banks provide the services of small money transfer but they actually make the transaction of millions of money all over the world each week. According to the World Bank, the annual global market for remittances - money transferred home from migrant workers - is around 167 billion US dollars. Remittances are also an important source of income for many developing countries including India, China and Mexico, all of which receive over 20 billion dollars each year in remittances from abroad.

Sa-Dhan, India's premier body of development finance institutions has reported the latest report on the status of microfinance in India for the FY2015-16. The report titled as Bharat Microfinance Report provides the latest data and statistics about the micro-finance sector in India. The next report with up-to-date statistics on Indian Microfinance Companies will be released in September 2017.

Microfinance has a long history of helping the bottom of the economic pyramid to build assets and achieve a standard of living. Indian Government has considerably enhanced allocation for the provision of education, health, sanitation and other facilities which promote capacity building and wellbeing of the poor. The Indian government puts emphasis on providing financial services to the poor and underprivileged since independence.

The microfinance sector has made tremendous growth today. The credit of such growth of Microfinance goes to national bodies like Small Industries Development Bank of 
India (SIDBI) and National Bank for Agriculture and Rural Development (NABARD). They have given a well recognition to Micro finance sector in India. The strength of the microfinance organizations (MFOs) in India is in the diversity of approaches and forms that have evolved over a period of time. While India has its home-grown model of SHGs, and mutually aided co- operative societies (MACS) there is significant learning from other microfinance experiments across the world, particularly Bangladesh, Indonesia and Thailand.

\section{CONCLUSION}

This research paper is completely based on the secondary data collection and therefore the accuracy and the reliability of the data is based on the same.

Economic and financial services institutions long term growth is depend on the manner that Financial Institutions approaches and taps untapped rural areas in India. Microfinance is often portrayed in literature as a tool that allows individuals excluded from the financial system to get access to sources of funding, which will help for theirs development and growth. From the above study it can be viewed that Self help Groups are playing vital role in delivery of microfinance services which leads to increase the saving habits of poorest strata of society and contributing towards the development of poor people in India.

Microfinance uses as a tool for eliminating poverty in India and other developing nations. Micro Finance Industry has the huge potential to grow in future, if this industry grows then one day we'll all see the new face of India, both in term of high living standard and happiness. After all, microfinance has the appeal of bringing financial power to the people who need it most and whose resourcefulness and ingenuity it will fuel. Nationalized banks have not encouraged loans for SHGs because of lack of creditworthiness, but these banks have excellent reach to SHGs so that they should come forward to exploit this business opportunity. SHG programme has indeed helped in the social and economic empowerment of rural poor, especially for women, time delivering essential and much-needed financial services at low transaction costs for banks, poor borrowers and villagers. However, slow progress of graduation of SHG members, poor quality of group functioning, dropout of members from groups etc., have also been reported various study findings in different parts of the country, which need to be taken into account while designing the road map for the next phase of the SHG programme The microfinance institution (development and regulation) bill, 2012 has passed to design interventions that increase the impact of microfinance on borrowers, lenders, company and other institutions. Further, bank officials do not have sufficient interest to go beyond their routine job, so that the aggressive drive for financial inclusion is attained. These problems are overcome in the microfinance institutions model. With more stable regulatory environment which provide steady availability of funds, improving profitability with comfortable asset quality \& capital adequacy and relatively lesser impact of concentration risk. Financial inclusion has been recognized as a priority goal of the microfinance sector and efforts were made in this report to identify the critical areas of interventions for greater success of the initiatives in the future.

The importance of microfinance in the developing countries like India cannot be undermined it play a vital role for socio-economic uplift of poor and low income peoples. Since 1990s, poverty reduction has taken priority at both national and international development levels. Within this framework, various initiatives have been taken by government. Microfinance has caught the attention as an effective tool for poverty reduction and socio- economic development. Hence Microfinance can play a vital role for improving the standard of living of poor. The economic development of any country is severely influenced by the availability of financial services. Microfinance is the form of a broad range of financial services such as deposits, loans, payment services, money transfers, insurance, savings, micro-credit etc. to the poor and low income individuals. A well- developed financial system promotes investment opportunities in an economy. Therefore it is necessary that govt. of India have to focus on extending financial services to both rural and urban to ensure sustainable and inclusive growth. From the above study it can be viewed that SHG's and MFI's are playing a vital role in delivery of microfinance services which leads development of 
poor and low income people in India. However, slow progress of graduation of SHG members, poor quality of group functioning, dropout of members from groups etc., have also been reported various study findings in different parts of the country, which need to be taken into account while designing the road map for the next phase of the SHG programme.

\section{RECOMMENDATIONS}

When there was the introduction of microfinance, no close focus was made on the regulation and individual institutions were free to bring in innovative operational models. However, with the passage of time as the sector grew the government made certain regulations so that the interest of the stakeholders can be protected and the micro finance sector can be developed.

Microfinance sector is based on many rules and regulations, very often field visits can be adopted as a medium for monitoring the conditions on ground and initiating corrective action if needed. This will help to have the information about the staff working on ground level and also on their recovery practices. It will also encourage MFIs to abide by proper code of conduct and work more efficiently.

It has been seen that in lieu of reducing the initial cost, MFIs are opening their branches in places which already have a few MFIs operating. Encouraging MFIs for opening new branches in areas of low microfinance penetration by providing financial assistance will increase the outreach of the microfinance in the state and check multiple lending. This will also increase rural penetration of microfinance in the state.

MFIs should provide range of products to the poor or low income people. These products may include financial services like deposits, instalment payments, loans, money payment services, money transfers, insurance, savings, and micro-credit services to the poor and low income individuals. They also provide training and support to these people for the use of such products and services. MFIs provide all the financial services to the rural people where people do not have access to banks.

It has been observed that MFIs often allow different patterns of charging interest rates and few of them also charge additional charges and interest free deposits. This is the reason for the borrowers to feel incompetent in terms of bargaining power. So in order to make the Microfinance sector more competitive it will be beneficial to follow a common practice for charging interest by all MFIs. MFIs should use new technologies and IT tools \& applications so that they can reduce their operating costs. They should also apply cost effective measures in order to reduce such costs. In absence of adequate funds the growth and the reach of MFIs become restricted and to overcome this problem MFIs should look for other sources for funding their loan portfolio.

\section{REFERENCES}

1. ADRA-Nepal (2006), "Key Principle and Characteristics of Micro Finance" https://www.scribd.com/doc/25094006/Key-Principle-and-Characteristics-of-MicroFinance

2. Al-Kake, F. (2019) problems of Internal Auditing in the Educational Sector (A Field study at the private university in Erbil - Iraq). Journal of Arts, Literature, Humanities and Social Sciences, 35(1)

3. Al-Kake, F., Ahmed, Dler Mousa (2019) The Role Of The Sarbanes-Oxley Act (Sox) In Reducing Agency Costs Exploratory Study Of A Sample Of Auditors In The Kurdistan Region Of Iraq. Qalaai Zanist Journal, 4(2).

4. Dixit, P. and Lal, R. C. (2016) "Role of Gandhi's Khadi Textile Industry towards Inclusive Growth and Corporate Social Responsibility", Int. J. of Trade and Commerce-IIARTC, Vol. 5, No. 1, pp. 115-120, DOI 10.13140/RG.2.2.36573.26086.

5. Dixit, P., Lal, R. C. (2019), "Inclusive Growth and Social Responsibility - A Critical Analysis of Indian Textile Industry", MERC Global"s International Journal of Management, Vol. 7, Issue 2, pp. 202-210. 
6. Dixit, P., Tyagi, A. (2018) "A Study of Downturn Trends of Crude Oil Price - An Economic Advantage for Indian Government and Consumers" 10.13140/RG.2.2.27345.79207.

7. FinDevGateway (2019), "MICROFINANCE FAQS" "What is microfinance" https://www.microfinancegateway.org/what-is-microfinance.

8. India Microfinance (2017), "Bharat Microfinance Report 2017-18", http://indiamicrofinance.com/2017-2016-bharat-report.html

9. International Journal of Current Research and Academic Review 1(1), 78-83.

10. M.Kannan and A. Panneerselvam (2013), "The microfinance in India- An overview",

11. Ministry of Finance (2012), "The Micro Finance Institutions (Development and Regulation) Bill, 2012", "PRS Legislative Research", "http://www.prsindia.org/billtrack/themicro-finance-institutions-development-and-regulation-bill-2012-2348/".

12. Mousa qadrAhmed, D., \& Al, F. A. K. A. K. (2019). Application of Accrual Basis in the Public Sector and its Role in Providing Useful Information Exploratory Study of a Sample of Academic Specialists in the Kurdistan Region of Iraq. Qalaai Zanist Journal, 4(1).

13. Nag, Jayeek (2019) MicroFinance Current Status and Growing Concerns in India http://www.academia.edu/6800954/MicroFinance_Current_Status_and_Growing_Concer ns_in_India.

14. Pankaj Dixit, Ramyar Rzgar Ahmed, Arvind Kumar Yadav and R. C. Lal (2019). Diversification of economy - an insight into inclusive growth \& food security with special reference to Pakistan's agriculture economy. Asian Journal of Agriculture and Rural Development, 9(1), 82-98.

15. Pankaj, D., Lal, R. (2019). A Critical Analysis of Indian Textile Industry: An Insight Into Inclusive Growth And Social Responsibility. Russian Journal of Agricultural and SocioEconomic Sciences, 88(4), 53-61. doi:10.18551/rjoas.2019-04.08.

16. Pankaj, D., Ramyar, R. (2019). Diversification of Economy - An Insight into Economic Development with Special Reference to Kurdistan"s Oil Economy and Agriculture Economy. Russian Journal of Agricultural and Socio-Economic Sciences, 85(1), 395-404.

17. Pankaj, D., Ramyar, R. (2019). Economic Diversification: An Insight into Sustainable and Inclusive Agriculture with Special Reference To Pakistan. Russian Journal of Agricultural and Socio-Economic Sciences, 85(1), 32-44

18. Reserve Bank of India (2008), "Publication-Micro Finance", https://www.rbi.org.in/scripts/publicationsview.aspx?id=10932

19. Roy, Suranjana (2016), "India's microfinance industry clocked $60 \%$ growth in fiscal 2016 : Report", "Live mint" http://www.livemint.com/Industry/4Zb0zp5yOhOtoqEdBFz4jL/Indiasmicrofinance-industry- clocked-60-growth-in-fiscal-2.html.

20. Tripathi, Vivek and Tripathi, Vineet, Recent Development of Microfinance in India (July 3, 2014). Available at SSRN: https://ssrn.com/abstract $=2462251$

21. UK ESSAYS (2017), "The concepts of microfinance and microcredit", https://www.ukessays.com/essays/economics/the-concepts-of-microfinance-andmicrocredit- economics-essay.php 